DOI: https://doi.org/10.33330/jurteksi.v5i1.270

Available online at http://jurnal.stmikroyal.ac.id/index.php/jurteksi

\title{
Media Informasi Pengenalan Penyakit Demam Berdarah Dengue Berbasis Android
}

\author{
Ketut Gus oka Ciptahadi, \\ Sistem Informasi, STIKOM Bali \\ email:okaciptahadi@stikom-bali.ac.id
}

\begin{abstract}
Dengue Hemorrhagic Fever, or commonly abbreviated as DHF, is a disease that has always been anxious in the community, especially during the rainy season, dengue disease outbreaks are increasing As in the northern city of Denpasar, the number of people affected by DHF, especially those aged 7-12 years is increasing. Coupled with the lack of information media facilities that can cause still many people, especially those aged 7-12 years who have not fully understood the dengue epidemic. the authors chose the location of the study, namely in one elementary school in the northern Denpasar area was SDN Negeri Tulang Ampiang. The problem found in this study is that it is less efficient and interesting for an information media about the dangers of dengue fever found in SDPN Negeri Tulang Ampiang school. Seeing the problem at the location of the study, the writer in this study will make an information media in the form of 3D animation, the introduction of Dengue Hemorrhagic Fever Based on Android. The author also in completing this research will use the approach through the Research and Development method, because in the final results of this study will produce a product. Testing in this study using the Black Box method that will test the functional requirements of the software that is built and use cousionary testing to test the information and visual aspects of the author's application.
\end{abstract}

Keywords: Dengue Hemorrhagic Fever, 3D Animation, Android, Research and Development.

\begin{abstract}
Abstrak: Demam Bedarah Dengue, atau biasa disingkat DBD adalah penyakit yang selalu menjadi keresahan pada masyarakat, apalagi pada saat musim hujan wabah penyakit DBD semakin meningkat Seperti pada kota Denpasar wilayah utara, jumlah masyarakat yang terkenana DBD, khususnya yang berusia 7-12 tahun semakin meningkat. Ditambah lagi dengan kurangnya sarana media informasi yang dapat megakibatkan masih banyaknya masyarakat khususnya yang berusia 7-12 tahun yang belum memahami betul terkait wabah penyakit DBD. penulis memilih lokasi penelitian yaitu pada salah satu sekolah dasar di wilayah Denpasar utara adalah SDPN Negeri Tulang Ampiang. Permaslahan yang terdapat pada penelitian kali ini adalah kurang efisien dan menariknya sebuah media informasi mengenai bahaya DBD yang terdapat pada sekolah SDPN Negeri Tulang Ampiang. Melihat permasalahan pada lokasi penelitian tersebut maka penulis dalam penelitian kali ini akan mebuat sebuah media informasi berupa animasi 3D pengenalan Penyakit Demam Berdarah Dengue Berbasis Android,. Penulis juga dalam menyelesaikan penelitian ini akan menggunakan pendekatan melalui metode Research and Development, dikarenakan pada hasil akhir penelitian ini akan menghasilkan sebuah produk. Pengujian pada penelitian ini menggunakan metode Black Box yang akan menguji dari persyaratan fungsional dari perangkat lunak yang dibangun serta menggunakan pengujian kousioner untuk menguji aspek informasi dan visual pada aplikasi penulis.
\end{abstract}

Kata kunci: Demam Berdarah Dengue, Animasi 3D, Android, Research and Development. 
DOI: https://doi.org/10.33330/jurteksi.v5i1.270

Available online at http://jurnal.stmikroyal.ac.id/index.php/jurteksi

\section{PENDAHULUAN}

Demam Bedarah Dengue, atau biasa disingkat DBD adalah penyakit yang selalu menjadi keresahan pada masyarakat, apalagi pada saat musim hujan wabah penyakit DBD semakin meningkat [1]. Seperti pada kota Denpasar wilayah utara, jumlah masyarakat yang terkenana DBD, khususnya yang berusia 7-12 tahun semakin meningkat. Ditambah lagi dengan kurangnya sarana informasi yang dapat megakibatkan masih banyaknya masyarakat khususnya yang berusia 7-12 tahun yang belum memahami betul terkait wabah penyakit DBD.

Dikarenakan lebih banyaknya masyarakat di denpasar utara yng berusia 7-12 tahun yang terkena kasus DBD, penulis pada penelitian kali ini, memilih lokasi penelitian yang lebih terdapat banyak responden dengan umur 7-12 tahun. yaitu pada salah satu sekolah dasar yang terfavorit di wilayah Denpasar utara: SDPN Negeri Tulang Ampiang. Ketika penulis melakukan observasi pada sekolah tersebut, penulis melihat beberapa media informasi kesehatan yang masih menggunakan visual berbasis $2 \mathrm{D}$ dan penyampaian informasi yang kurang begitu lengkap. Mengingat pentingnya sebuah penyampaian informasi yang lengkap dan visual yang menarik akan dapat dengan cepat memberikan pemahaman sebuah informasi atau himbauan kepada masyarakat. Permasalahan yang terdapat pada penelitian kali ini adalah kurang efisien dan menariknya sebuah media informasi mengenai bahaya DBD yang terdapat pada sekolah SDPN Negeri Tulang Ampiang. Penulis juga melakukan wewancara kepada pihak kepala sekolah yeng bernama I gusti ngurah Suteja.,M.Pd, menyatakan bahwa, "Kurangnya media infromasi yang baik pada sekolah kami, yang mengakibatkan masih banyak siswa kami yang belum paham betul mengenai penyakit demam berdarah, serta penyuluhan dari kantor puskesmas setempat yang tidak terlalu sering". Melihat dari permaslahan tersebut penulis ingin membuat media informasi yang lebih baik lagi dari segi visual yang menarik serta infromasi yang lebih lengkap menggunakan animasi 3D. Dengan adanya media informasi menggunakan animasi maka proses penyampaian suatu informasi akan lebih mudah untuk di pahami dan dimengerti dibandingkan menggunakan lisan maupun tulisan.[2].

Menurut Aditya, S.T dalam buku berjudul Panduan Mudah Membuat Visualisasi 3D Arsitektur, juga menyatakan dengan visualisasi grafis 3D komputer rancangan desain yang dibuat dapat ditampilkan senyata mungkin. Juga fitur-fitur 3D memberikan citra pewarnaan, material, maunpun pencahayaan yang realistis.[3]. Sekolah SDPN Negeri Tulang Ampiang juga memiliki fasilitas yang mendukung guna kelancaran penyuluhan media informasi terkait pemahaman dini penyakit demam berdarah dengue. Berupa adanya beberapa papan digital yang yang terdapat pada ruang kantin, perpustakaan dan ruang pengunjung, hal ini dipertegas oleh penulis ketika melakukan observasi langsung ke lokasi penelitian. Jumlah papan digital yang terdapat pada sekolah tersebut sebanyak 4 buah,

Media informasi yang dirancang peneliti akan menampilkan perkem- 
JURTEKSI (Jurnal Teknologi dan Sistem Informasi)

Vol. V No. 1, Des 2018, hlm. 53 - 60

DOI: https://doi.org/10.33330/jurteksi.v5i1.270

Available online at http://jurnal.stmikroyal.ac.id/index.php/jurteksi

bangbiakan nyamuk, bagaimana nyamuk itu menggigit manusia, menampilkan ekpresi dan gerakan tubuh sesorang yang terkena penyakit DBD \& penanggulangannya.

Penelitian ini juga nantinya menggunakan metode Research and Development, ditambah lagi untuk membuat hasil project media informasi dapat diterima oleh kalangan pelajar, khususnya bagi siswa sekolah dasar yang berada dilokasi penelitian akan melalui beberapa tahapan seperti penggalian informasi yang akurat melalui interview kepada para narasumber terkait permasalahan yang akan diteliti, melakukan observasi untuk menentukan penjadwalan terhadap narasumber. Terakhir adalah angket pengujian untuk proses evaluasi didalam pengeimplementasian media informasi yang dibuat. Pengujian pada penelitian ini menggunakan metode Black Box yang akan menguji dari persyaratan fungsional serta pengujian kuisioner yang akan menguji dari aspek informasi dan aspek visual animasi dari perangkat lunak yang dibangun. Sehingga akan dilakukan penelitian dengan judul penelitian "Animasi 3D Pengenalan Penyakit Demam Berdarah Dengue Berbasis Android".

\section{METODE}

Penulis didalam menyelesaikan terkait penelitiannya menggunakan pen-dekatan menggunakan metode penelitian R\&D (Research And Development). Sugiyono mendefinisikan metode penelitian dan pengembangan yaitu (Research And Development) atau disingkat dengan R\&D merupakan metode penelitian yang digunakan untuk menghasilkan produk tertentu, dan menguji keefektifan produk tersebut [4] Penulis membagi metode Reseach and Development menjadi 4 tahapan utama yaitu:

1.Tahap Studi Pendahuluan.

2.Tahap Pengembangan.

3. Tahap Evaluasi.

4.Tahap Dokumentasi.

\section{HASIL DAN PEMBAHASAN}

\section{Desain Produk}

Setelah peneliti melewati tahap pengupulan data, tahap selanjutnya adalah membuat perancangan desain untuk video animasi. Informasi, arahan dan masukan dari kepala sekolah SDPN Tulang Ampiang dan pegawai puskesmas Denpasar utara yang sudah didapat dimasukan kedalam rancangan desain yaitu storyboard. Dalam perancangan desain storyboard terdapat: desain produk, informasi, no scene, durasi. Berikut adalah hasil screenshot storyboard, desain yang dirancang.

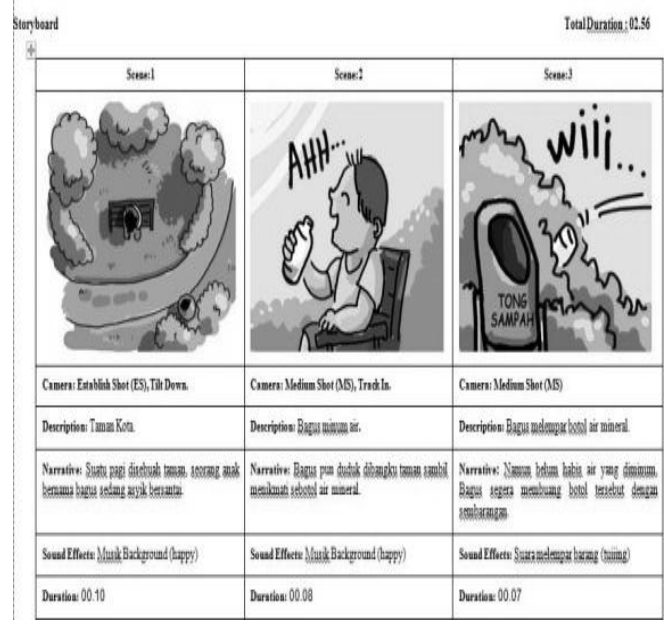

Gambar 1. Cuplikan Storyboard

\section{Validasi Desain}

Validasi desian yang dilakukan penulis berupa penilaian dari hasil 
Available online at http://jurnal.stmikroyal.ac.id/index.php/jurteksi

perancangan desain \& informasi yang sudah dirancang, dengan cara menunjukan hasil desain kepada kepala sekolah pada lokasi penelitian, berikutnya kepada pegawai Puskesmas yang berlokasi di Denpasar utara dan salah satu pakar ahli desain dan multimedia yang terdapat pada stikom bali. Berikut adalah sceenshot dari penilaian atau masukan dari validasi desain yang sudah dilakukan penulis.

Tabel 3. Responden SDPN Tulang

\begin{tabular}{|c|c|c|c|c|c|}
\hline \multicolumn{6}{|c|}{ Ampiang } \\
\hline \multirow{2}{*}{ Nama } & \multirow{2}{*}{ jabatan } & \multicolumn{4}{|c|}{ Penilaian\&masukan } \\
\hline & & $\begin{array}{c}\text { Grafis } \\
3 \mathrm{D}\end{array}$ & $\begin{array}{l}\text { Story } \\
\text { board }\end{array}$ & Informasi & Masukan \\
\hline $\begin{array}{c}\text { I Gusti } \\
\text { ngurah } \\
\text { Suteja, } \\
\text { MPd }\end{array}$ & $\begin{array}{l}\text { Kepala } \\
\text { Sekolah } \\
\text { SDPN } \\
\text { Negeri } \\
\text { Tulang } \\
\text { Ampiang }\end{array}$ & Setuju & $\begin{array}{l}\text { Sudah } \\
\text { sesuai }\end{array}$ & Lengkap. & $\begin{array}{c}\text { Untuk } \\
\text { pembuata } \\
\text { n animasi, } \\
\text { berikan } \\
\text { pewamaa } \\
\text { nyang } \\
\text { cerah } \\
\text { kama } \\
\text { responden } \\
\text { nya lebih } \\
\text { banyak } \\
\text { kalangan } \\
\text { SD. }\end{array}$ \\
\hline
\end{tabular}

Tabel 4. Staf Puskesmas Denud

\begin{tabular}{|c|l|c|c|c|l|}
\hline \multirow{2}{*}{ Nama } & \multirow{2}{*}{ jabatan } & \multicolumn{3}{|c|}{ Penilaian\&masukan } \\
\cline { 3 - 6 } & & $\begin{array}{c}\text { Grafis } \\
\text { 3D }\end{array}$ & $\begin{array}{l}\text { Story } \\
\text { board }\end{array}$ & Informasi & Masukan \\
\hline $\begin{array}{c}\text { Ni } \\
\text { Nyoman }\end{array}$ & $\begin{array}{l}\text { Staf } \\
\text { kesehatan } \\
\text { Sudarti.. } \\
\text { bidang } \\
\text { promosi } \\
\text { kesehatan. }\end{array}$ & Setuju & $\begin{array}{c}\text { Sudah } \\
\text { sesuai }\end{array}$ & Lengkap. & $\begin{array}{l}\text { Pada } \\
\text { cerita } \\
\text { dalam } \\
\text { animasi, } \\
\text { bisa } \\
\text { diberikan } \\
\text { unsur } \\
\text { komedi }\end{array}$ \\
& & & & & $\begin{array}{l}\text { agar } \\
\text { lebih } \\
\text { menarik. }\end{array}$ \\
\hline
\end{tabular}

Tabel 5. Staf Multimedia Stikom

\begin{tabular}{|c|c|c|c|c|c|}
\hline \multirow{2}{*}{ Nama } & \multirow{2}{*}{ jabatan } & \multicolumn{4}{|c|}{ Penilaian\&masukan } \\
\hline & & $\begin{array}{c}\text { Grafis } \\
\text { 3D }\end{array}$ & $\begin{array}{l}\text { Story } \\
\text { board }\end{array}$ & Informasi & Masukan \\
\hline $\begin{array}{l}\text { I Made } \\
\text { Suandan } \\
\text { a. Astika } \\
\text { Pande, } \\
\text { S.Kom }\end{array}$ & $\begin{array}{c}\text { Staf } \\
\text { multimedia } \\
\text { (STMIK } \\
\text { STIKOM } \\
\text { Bali) }\end{array}$ & $\begin{array}{l}\text { Sangat } \\
\text { baik. }\end{array}$ & $\begin{array}{l}\text { Sudah } \\
\text { sesuai }\end{array}$ & Lengkap. & $\begin{array}{l}\text { Pewama } \\
\text { aan } \\
\text { untuks } \\
\text { modeling } \\
\text { diharapk } \\
\text { an } \\
\text { menggun } \\
\text { akan } \\
\text { penggab } \\
\text { ungan } \\
\text { texture } \\
\text { agar } \\
\text { lebih } \\
\text { terlihat } \\
\text { realistis }\end{array}$ \\
\hline
\end{tabular}

\section{Implementasi}

Berikut ini penulis akan menampilkan beberapa hasil dari setiap tahapan perancangan animasi. Dimulai dari pembuatan modeling, rigging, animasi, rendering hingga perancangan interface aplikasi android.

\section{Karakter 3D}

Penulis membuat modeling 3D, dengan menggunakan cube lalu diektrude keatas dan kebeawah mengikuti blurprint yang sudah penulis desain.

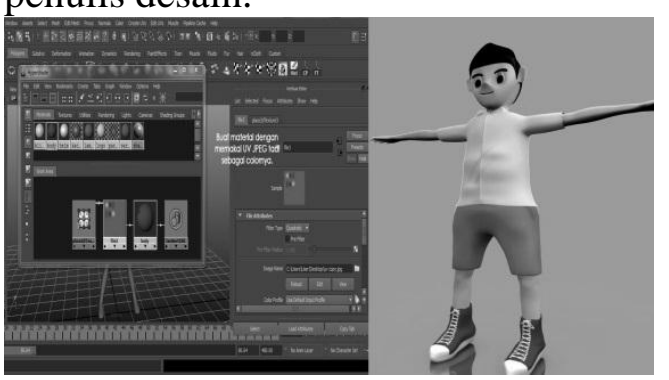

Gambar 1. Pembuatan Karakter

\section{Setup Rigging Karakter}

Setelah proses modeling selesai, dilanjutkan dengan pembuatan tulang, pada penelitian ini pembauatn tulang dilakukan secara manual guna mengurangi proses terjadinya eror pada karakter.

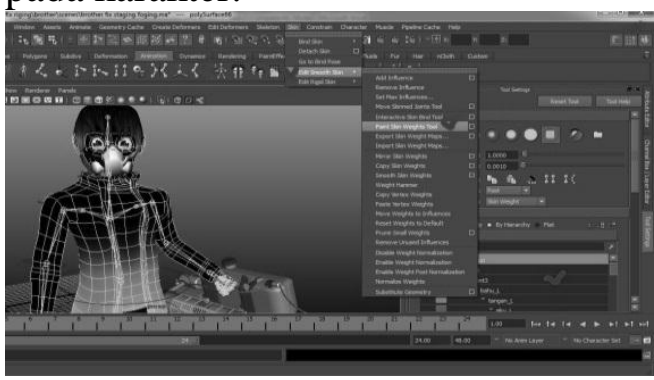

Gambar 2. Setup Karakter

\section{Animasi}

Dilanjutkan dengan proses animasi, animasi dilakukan dengan meng-gerakan setiap kontroler yang ada pada setiap bagian tulang dengan 
DOI: https://doi.org/10.33330/jurteksi.v5i1.270

Available online at http://jurnal.stmikroyal.ac.id/index.php/jurteksi

digerakan satu persatu. Gerakn dikunci pada bagian frame yang terdapat pada timeline.

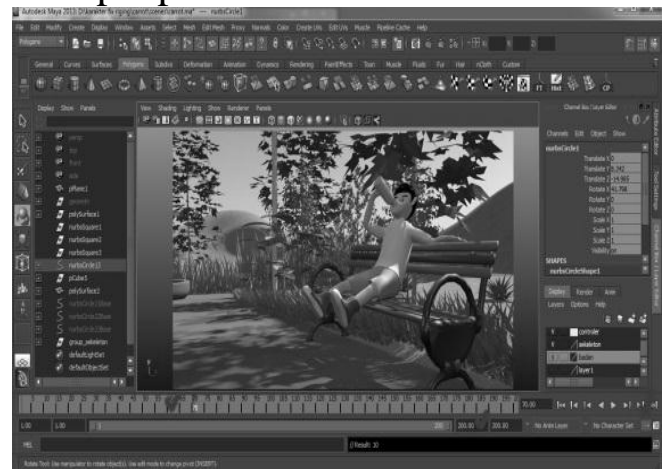

Gambar 3. Pembuatan Animasi

\section{Tampilan Aplikasi Halaman Utama}

Di halaman utama terdapat 4 tombol, yang pertama tombol informasi untuk memberikan penjelasan terkait informasi demam berdarah. Tombol video untuk menampilkan video beserta deskripsinya, tombol about us, untuk menampilkan informasi penulis dan tombol keluar yang disimbolkan dengan simbol panah untuk keluar aplikasi.
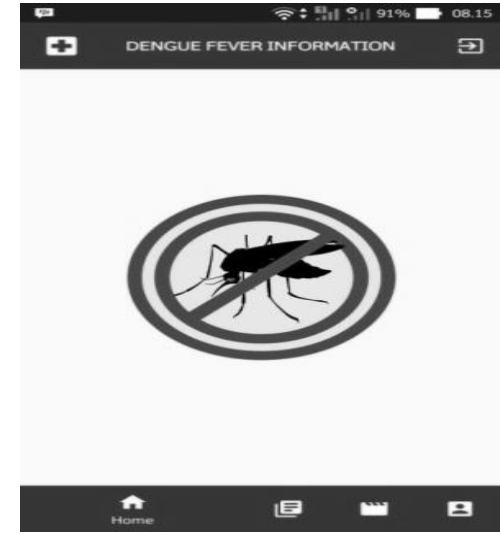

Gambar 4. Halaman Utama

\section{Tampilan Aplikasi Halaman Informasi}

Berikutnya adalah halaman informasi, pada halaman ini pengguna bisa melihat informasi tentang demam berdarah dengue, seperti: pengenalan demam berdarah dengue, sirkulasi singkat virus demam berdarah dengue, serta pengaruh virus demam berdarah dengue.

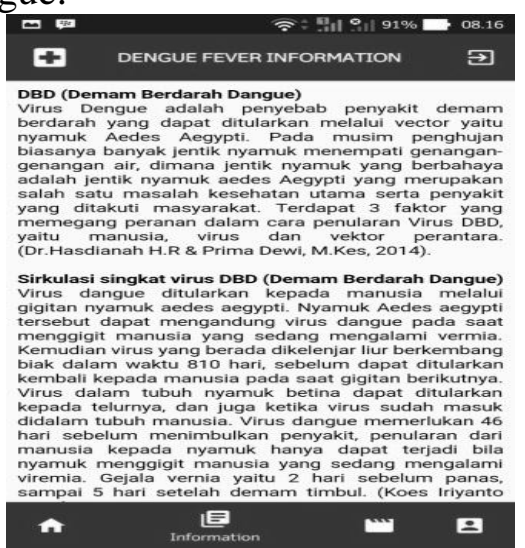

Gambar 5 Halaman Informasi

\section{Tampilan Aplikasi Halaman Video}

Berikutnya adalah halaman video, pada halaman ini pengguna bisa melihat video animasi tentang demam berdarah dengue. Video tersebut memiliki durasi 03.56 serta terdapat deskripsi singkat mengenai pemahaman demam berdarah.
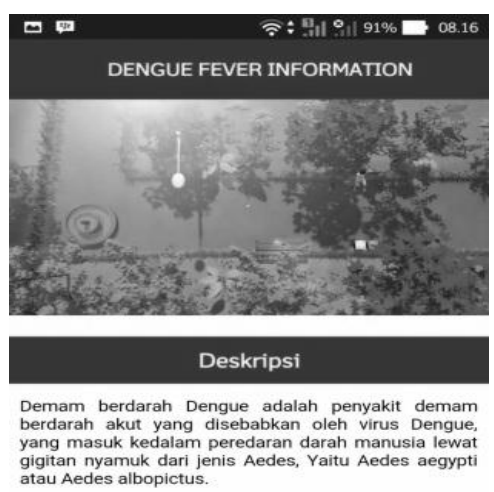
n 目
Gambar 6. Halaman video

Tampilan Aplikasi Halaman About

Pada halaman ini pengguna bisa melihat informasi singkat mengenai 
Vol. V No. 1, Des 2018, hlm. 53 - 60

DOI: https://doi.org/10.33330/jurteksi.v5i1.270

Available online at http://jurnal.stmikroyal.ac.id/index.php/jurteksi

data diri penulis serta foto dari penulis.

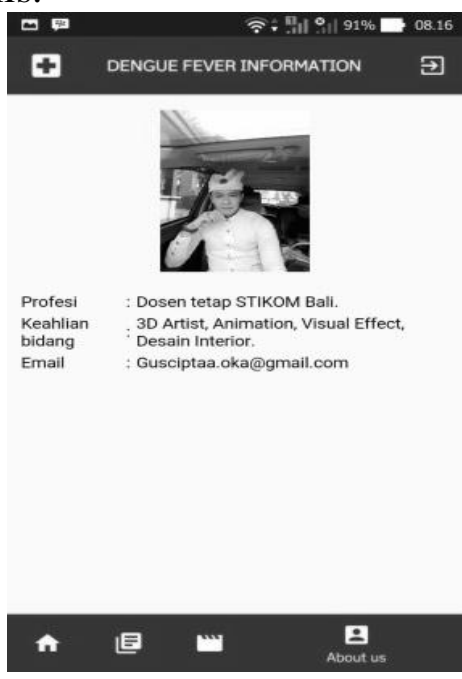

Gambar 7. Halaman tentang

\section{Pengujian Black Box}

Metode yang digunakan dalam pengujian black box yang fokus pada persyaratan fungsional dari perangkat lunak yang dibangun. Hasil pengujian black box pada aplikasi pengenalan demam berdarah dengue dijelaskan pada tabel dibawah.

\section{Indikator dan Sub Indikator Kuisioner}

Didalam penggunaan kuisioner, penulis membaki pertanyaan kedalam 4 indikator. Kesemua indikator dibreakdown lagi menjadi sub indikator. Berikut adalah hasil dari indikator dan sub indikator dari kuisioner. dibagikan kepada responden.

Tabel 6. Pengujian black box

\begin{tabular}{|c|c|c|c|}
\hline $\begin{array}{c}\text { Aktifitas } \\
\text { Pengujian } \\
\text { Klik tombol } \\
\text { ikon aplikasi }\end{array}$ & $\begin{array}{l}\text { Realisasi } \\
\text { diharapkan } \\
\text { Untuk memutar flash screen } \\
\text { logo aplikasi. }\end{array}$ & \begin{tabular}{l}
\multicolumn{1}{c}{ Hasil } \\
Pengujian \\
Flash screen dapat \\
diputar
\end{tabular} & $\begin{array}{l}\text { [ v ] Diterima } \\
\text { [ ] Ditolak }\end{array}$ \\
\hline $\begin{array}{l}\text { Klik tombol } \\
\text { ikon } \\
\text { informasi }\end{array}$ & $\begin{array}{l}\text { Untuk menampilkan informasi } \\
\text { pengenalan DBD }\end{array}$ & $\begin{array}{l}\text { Halaman Informasi dapat } \\
\text { ditampilkan }\end{array}$ & $\begin{array}{l}\text { [ v ] Diterima } \\
\text { [ ] Ditolak }\end{array}$ \\
\hline $\begin{array}{l}\text { Klik tombol } \\
\text { ikon video }\end{array}$ & $\begin{array}{l}\text { Untuk menampilkan halaman } \\
\text { video }\end{array}$ & $\begin{array}{l}\text { Halaman Petunjuk } \\
\text { Penggunaan dapat } \\
\text { ditampilkan }\end{array}$ & $\begin{array}{l}\text { [ v ] Diterima } \\
\text { [ ] Ditolak }\end{array}$ \\
\hline $\begin{array}{l}\text { Klik tombol } \\
\text { ikon Play } \\
\text { pada video }\end{array}$ & Untuk memutar video animasi & $\begin{array}{l}\text { Video animasi dapat } \\
\text { diputar }\end{array}$ & $\begin{array}{l}\text { [ v ] Diterima } \\
\text { [ ] Ditolak }\end{array}$ \\
\hline $\begin{array}{l}\text { Klik tombol } \\
\text { ikon Tentang }\end{array}$ & $\begin{array}{l}\text { Untuk menampilkan halaman } \\
\text { Tentang }\end{array}$ & $\begin{array}{l}\text { Halaman Tentang dapat } \\
\text { ditampilkan }\end{array}$ & $\begin{array}{l}\text { [ v ] Diterima } \\
\text { [ ] Ditolak }\end{array}$ \\
\hline $\begin{array}{l}\text { Klik tombol } \\
\text { Keluar }\end{array}$ & $\begin{array}{l}\text { Untuk menampilkan pop up } \\
\text { keluar }\end{array}$ & $\begin{array}{l}\text { Pop up keluar berhasil } \\
\text { ditampilkan }\end{array}$ & $\begin{array}{l}\text { [ v ] diterima } \\
{[\text { ] ditolak }}\end{array}$ \\
\hline
\end{tabular}

Tabel 7. Indikator kuisioner

\begin{tabular}{|c|c|c|c|}
\hline No & Indikator & Sub Indikator & No Soal \\
\hline \multirow{2}{*}{1.} & \multirow{2}{*}{ Desain Iklan } & a) Pewarnaan & 1 \\
\hline & & b) Bentuk karakter & 2,3 \\
\hline \multirow{5}{*}{2.} & \multirow{5}{*}{ Informasi } & a) Penyajian Informasi & 4 \\
\hline & & b) Kelengkapan Informasi & 5 \\
\hline & & c) Tujuan Iklan & 6,7 \\
\hline & & d) Pengetahuan & 8 \\
\hline & & e) Bahasa yang digunakan & 9 \\
\hline \multirow{2}{*}{3.} & \multirow{2}{*}{ Pengisian suara \& musik } & a) Kejelasan suara & 10 \\
\hline & & b) Musik pengiring & 11 \\
\hline 4. & Alur cerita & c) Jalan cerita & 12 \\
\hline
\end{tabular}


JURTEKSI (Jurnal Teknologi dan Sistem Informasi)

Vol. V No. 1, Des 2018, hlm. 53 - 60

DOI: https://doi.org/10.33330/jurteksi.v5i1.270

Available online at http://jurnal.stmikroyal.ac.id/index.php/jurteksi

\section{Pengujian Kuisioner}

Pengujian yang dilakukan oleh penulis berikutnya dengan menggunakan angket kuisioner, pengujian kuisioner dilakukan guna mendapatkan hasil positif dari penggunakan media animasi bebasis android. Responden dari pengujian tersebut adalah siswa dari SDPN Tulang Ampiang yang dikhususkan untuk umur 7-12 tahun dan berjumlah 90 responden. Berikut adalah daftar indikator yang akan diuji beserta hasil frekuensi pengujian media informasi menggunakan kuisioner.

Tabel 8. Hasil frekuensi Kusioner

\begin{tabular}{|c|l|l|l|l|l|l|l|l|}
\hline $\begin{array}{c}\text { Tanggapan } \\
\text { Responden }\end{array}$ & \multicolumn{2}{|c|}{$\begin{array}{c}\text { Sangat } \\
\text { tidak baik }\end{array}$} & \multicolumn{2}{|c|}{ Tidak baik } & \multicolumn{3}{c|}{ Baik } & \multicolumn{2}{c|}{ Sangat baik } \\
\hline Soal & F & $\%$ & F & $\%$ & F & $\%$ & F & $\%$ \\
\hline 1 & 0 & 0 & 4 & 4.4 & 62 & 68.9 & 24 & 26.7 \\
\hline 2 & 0 & 0 & 5 & 5.6 & 60 & 66.7 & 25 & 27.8 \\
\hline 3 & 0 & 0 & 0 & 0 & 59 & 65.6 & 31 & 34.4 \\
\hline 4 & 0 & 0 & 2 & 2.2 & 46 & 51.1 & 42 & 46.7 \\
\hline 5 & 0 & 0 & 2 & 2.2 & 56 & 62.2 & 32 & 35.6 \\
\hline 6 & 0 & 0 & 2 & 2.2 & 47 & 52.2 & 41 & 45.6 \\
\hline 7 & 0 & 0 & 0 & 0 & 49 & 54.4 & 41 & 45.6 \\
\hline 8 & 0 & 0 & 2 & 2.2 & 43 & 47.8 & 45 & 50 \\
\hline 9 & 0 & 0 & 4 & 4.4 & 54 & 60 & 32 & 35.6 \\
\hline 10 & 0 & 0 & 5 & 5.6 & 61 & 67.8 & 24 & 26.7 \\
\hline 11 & 1 & 1.1 & 3 & 3.3 & 65 & 72.2 & 21 & 23.3 \\
\hline 12 & 0 & 0 & 2 & 2.2 & 50 & 55.6 & 38 & 42.2 \\
\hline
\end{tabular}

\section{Deskripsi Hasil pembahasan} Frekuensi

Berdasarkan tabel frekuensi jawaban responden dari pengunjung/pasien puskesmas terlihat bahwa sebagian besar persentase jawaban berada pada kategori baik yaitu diatara $50 \%$ sampai dengan $74.99 \%$ jadi dapat dikatakan hasil pengujian iklan animasi $3 \mathrm{~d}$ untuk penyakit demam berdarah dengue yang terdiri dari aspek desain iklan, informasi, alur cerita dan bahasa sudah baik.

\section{SIMPULAN}

Kesimpulan yang didapat dari penelitian ini adalah, penulis sudah dapat membuat satu buah video animasi yang dikemas dalam bentuk aplikasi andorid. Bertujuan untuk memberikan pemahaman terkait penyakit demam berdarah dengue kepada masyarakat, khususnya remaja yang berusia 7-12 tahun. Pengujian dari penelitian ini ada 2, pertama menggunakan pengujian black box yang bertujuan untuk menguji fungsional dari aplikasi tersebut. Hasil dari penggujian black box tersebut menyatakan fungsional aplikasi penelitian berjalan baik dan dapat dikatakan valid. Pengujian kedua menggunakan kusioner yang bertujuan untuk mendapatkan respon postif dari responden terkait pennyampaian informasi menggunakan animasi 3D berbasis android. Hasil dari pengujian kuisioner dikategorikan baik karena berdasarkan tabel frekuensi jawaban dari responden SDPN Negeri Tulang Ampiang, terlihat bahwa sebagian besar persentase jawaban berada pada 
DOI: https://doi.org/10.33330/jurteksi.v5i1.270

Available online at http://jurnal.stmikroyal.ac.id/index.php/jurteksi

kategori baik yaitu diatara $50 \%$ sampai dengan $74.99 \%$. Jadi dapat dikatakan hasil pengujian dari media informasi animasi 3d untuk penyakit Demam Berdarah Dengue berbasis android, yang terdiri dari aspek desain iklan, informasi, alur cerita dan bahasa sudah baik.

\section{UCAPAN TERIMA KASIH}

Penulis mengucapkan rasa syukur dan terima kasih, kepada Tuhan Yang Maha Esa karena Atas berkat dan rahmatnya, penulis akhirnya dapat menyelesaikan penelitian ini dengan baik, lancar dan tepat waktu. serta kepada pihak yang sudah membantu demi kelancaran proses penelitian ini yaitu pihak SDPN Tulang Ampiang, pihak staf Puskesmas Denpasar Utara dan staf ahli multimedia yang terdapat pada kampus STIKOM Bali.

\section{DAFTAR PUSTAKA}

[1] Dr.Hasdianah H.R, \& Prima Dewi, M.Kes. (2014) .VirologiMengenal Virus, Penyakit, Dan Pencegahannya, Nuha Medika, 2014.

[2] R. Pangemanan, Sengkey, Oktavian A. Lantang, (2016) .Perancangan Animasi 3 Dimensi Alur Pengurusan Administrasi Pasien Umum Dan Jaminan Dibagian Rehabilitasi Medik RSUP Prof. DR. R.D Kandou Manado", E-journal Teknik Informatika, Volume 9, No 1.

[3] Aditya. (2021). Panduan Mudah Membuat Visualisasi 3D Arsitektural, Jakarta: Griya Kreasi.

[4] Sugiyono. (2013) Metode Penelitian Kuantitatif, Kualitatif, dan R\&D. Bandung:Alfabeta 